NBER WORKING PAPER SERIES

\title{
GRAVITY CHAINS: ESTIMATING BILATERAL TRADE FLOWS WHEN PARTS AND COMPONENTS TRADE IS IMPORTANT
}

\author{
Richard Baldwin \\ Daria Taglioni \\ Working Paper 16672 \\ http://www.nber.org/papers/w16672
NATIONAL BUREAU OF ECONOMIC RESEARCH
1050 Massachusetts Avenue
Cambridge, MA 02138
January 2011

We would like to thank participants at workshop at the WTO and Oxford. The views expressed in this paper are those of the authors and do not necessarily represent those of the European Central Bank or the National Bureau of Economic Research.

NBER working papers are circulated for discussion and comment purposes. They have not been peerreviewed or been subject to the review by the NBER Board of Directors that accompanies official NBER publications.

(C) 2011 by Richard Baldwin and Daria Taglioni. All rights reserved. Short sections of text, not to exceed two paragraphs, may be quoted without explicit permission provided that full credit, including (C notice, is given to the source. 
Gravity Chains: Estimating Bilateral Trade Flows When Parts And Components Trade Is Important Richard Baldwin and Daria Taglioni

NBER Working Paper No. 16672

January 2011, Revised June 2011

JEL No. F1,F15

\begin{abstract}
$\underline{\text { ABSTRACT }}$
Trade is measured on a gross sales basis while GDP is measured on a net sales basis, i.e. value added. The rapid internationalisation of production in the last two decades has meant that gross trade flows are increasingly unrepresentative of the value added flows. This fact has important implications for the estimation of the gravity equation. We present empirical evidence that the standard gravity equation performs poorly by some measures when it is applied to bilateral flows where parts and components trade is important. We also provide a simple theoretical foundation for a modified gravity equation that is suited to explaining trade where international supply chains are important.
\end{abstract}

\author{
Richard Baldwin \\ Graduate Institute, Geneva \\ Cigale 2 \\ 1010 Lausanne \\ SWITZERLAND \\ and CEPR \\ and also NBER \\ baldwin@graduateinstitute.ch \\ Daria Taglioni \\ Centre for Trade and Economic Integration \\ Institut de hautes études internationales \\ et du développement \\ The Graduate Institute of International \\ and Development Studies Case \\ postale 136 - CH - 1211 Genève 21 - Suisse \\ daria.taglioni@graduateinstitute.ch
}




\section{INTRODUCTION}

Trade is measured on a gross sales basis while GDP is measured on a value added basis. For the first decades of the postwar period, this distinction was relatively unimportant. Trade in intermediates was always important, but it was quite proportional to trade in final goods. The rapid internationalisation of supply chains in the last two decades has changed this (Yi 2003). Indeed, such trade has in recent decades boomed between advanced nations and emerging economies as well as among emerging nations - especially in Asia, where the phenomenon is known as "Factory Asia". There are, however, similar supply chains in Europe and between the US and Mexico (Kimura, Fukunari, Yuya Takahashi and Kazunobu Hayakawa 2007). As a result, gross trade flows are increasingly unrepresentative of the value-added flows. This fact has important policy implications (Lamy 2010), but it also has important implications for one of trade economists' standard tools - the gravity equation.

The basic point is simple. The standard gravity equation is derived from a consumer expenditure equation with the relative price eliminated using a general equilibrium constraint (Anderson 1979 , Bergstrand 1985, 1989, 1990). The corresponding econometrics widely used today is based on this theory (Anderson and Van Wincoop 2003). As such the standard formulation bilateral trade regressed on the two GDPs, bilateral distance and other controls - is best adapted to explaining trade in consumer goods. When consumer trade dominates, the GDP of the destination nation is a good proxy for the demand shifter in the consumer expenditure equation; the GDP of the origin nation is a good proxy of its total supply. By contrast, when international trade in intermediate goods dominates, the use of GDPs for the supply and demand proxies is less appropriate.

Consider, for instance, the determinants of Thai imports of auto parts from the Philippines. The standard formulation would use Thai GDP to explain Thailand's import demand, however, the underlying demand for parts is generated by Thai gross production of autos, not its value-added in autos. As long as the ratio of local to imported content does not change, value added is a reasonable proxy for gross output, so the standard regression is likely to give reasonable results. However, for regions where production networks are emerging, value added can be expected to be a poor proxy.

Why do incorrectly specified mass variables matter? A large number of gravity studies focus on variables that vary across country pairs - say free trade agreements, cultural ties, or immigrant networks. The most recent of these studies employ estimators that control for the mass variables with fixed effects. Such studies do not suffer from mass-variable mis-specification and so are unaffected by our critique. There are however a number of recent studies - especially concerning the 'distance puzzle' that do proxy for the production and demand variables with GDP. It is these studies that our work speaks to.

For example, Rauch (1999), Brun et al (2005), Berthelon and Freund (2008), and Jacks et al (2008) use GDP as the mass variable when they decompose the change in the trade flow into the effects of income changes and trade cost changes; Anderson and Van Wincoop (2003) also use GDP as the mass variable in one of their estimation techniques. Since most of these studies are concerned with a broad set of nations and commodities, the mis-specification of the mass variable probably has a minor impact on the results - as the findings of Bergstrand and Egger (2010) showed. More worrying, however, is the use by authors that focus on trade in parts and 
components such as Athukorala and Yamashita (2006), Kimura et al (2007), Yokota and Kazuhiko (2008), and Ando and Kimura (2009). These papers all use the consumer good version of the gravity model to describe parts and components trade and thus have mis-specified the mass variable.

\section{Literature review}

There is nothing new about trade in intermediates. Intermediates have long been important in the trade between the US and Canada; the 1965 US-Canada Auto Pact, for example, explicitly targeted preferential tariff reductions on cars and cars parts. It has also long been important within Western Europe as early studies of the EEC demonstrated (e.g. Dreze 1961, Verdoorn 1960, and Balassa 1965, 1966). The famous book by Grubel and Lloyd (1975), made clear that much of intra-industry trade was in intermediates, not final goods, and the importance of intermediates was reflected in early work by well-known theorists. For example, Vaneck (1963) presents an extension of the Heckscher-Ohlin model that allows for intermediates trade, and Ethier (1981) casts his model of intra-industry trade in a world where all trade was in intermediates.

As better data and computing technology became available, the importance of intermediates in trade was rediscovered and documented more thoroughly. In the context of efforts to understand the impact of the EU's Single Market Programme, European scholars focused on the role of intermediates. For example, Greenaway and Milner (1987) list this as one of the 'unresolved issues', writing "it is becoming increasingly obvious that a significant proportion of measured IIT is accounted for by trade in parts and components. [Nevertheless,] most of the models developed so far assume trade in final goods. The modelling of trade in intermediates needs to be explored further." The issue attracted renewed interest following development of the new trade theory in the 1980s (Helpman and Krugman 1985) ${ }^{1}$ and again in the 1990s with Jones and Kierzkowski (1990), and Hummels, Rapoport and Yi (1998)², and more recently Kimura, Takahashi and Hayakawa (2007), and Grossman and Rossi-Hansberg (2008).

The traditional gravity model was developed in the 1960s to explain factory-to-consumer trade (Tinbergen 1962, Poyhonen 1963, Linnemann 1966). This concept is at the heart of the first clear microfoundations of the gravity equation - the seminal Anderson (1979). ${ }^{3}$ This article proposed a theoretical explanation of the gravity equation based on CES preferences when nations make a single differentiated product. Anderson and Van Wincoop (2003) use the Anderson (1979) theory to develop appropriate econometric techniques. Subsequent theoretical refinements have focused on showing that the gravity equation can be derived from many different theoretical

\footnotetext{
${ }^{1}$ As illustrated by the Brookings Institution book "The global factory: Foreign assembly in international trade" (Grunwald and Flam 1985).

${ }^{2}$ Feenstra (1998) for a survey of the 1990s literature.

${ }^{3}$ Leamer and Stern (1970) informally discusses three economic mechanism that might generate the gravity equations but these were based on rather exotic economic logics; Anderson (1979) was the first to provide clear microfoundations that rely only on assumptions that would strike present-day readers as absolutely standard.
} 
frameworks (including monopolistic competition, and Melitz-type trade models with heterogeneous firms). ${ }^{4}$

Studies on the gravity equations applicability to intermediate goods trade are more limited. These include Egger and Egger (2004), and Baldone et al (2007). The study that is closest to ours is Bergstrand and Egger (2010). These authors develop a computable general equilibrium model that explains the bilateral flows of final goods, intermediate goods and FDI. Calibration and simulation of the model suggests a theoretical rationale for estimating a near-standard gravity model for the three types of bilateral flows. Using a large dataset on bilateral flows of final and intermediate goods trade, and a dataset on bilateral FDI flows, they estimate the three equations and find that the standard gravity variables all have the expected size and magnitude.

The value added of our paper is primarily empirical - to show that the standard gravity specification performs poorly when applied to flows where trade in intermediates is important. Moreover, the failures line up with the predictions of our simple theory model that suggests a gravity equation formulation that is appropriate to intermediates trade. Note that when we perform the estimates on data pooled across a wide range of nations - as do Bergstrand and Egger (2010) - we find the same results, namely that the standard specification performs well.

We believe the difference in the results is due to the fact that for many trade flows, the pattern of trade in intermediates is quite proportional to trade in final goods. This is especially for trade among developed nations.

\section{Plan of the paper}

The paper starts with simple theory that generates a number of testable hypotheses. We then confront these hypotheses with the data and find that the estimated coefficients deviate from standard results in the way that the simple theory says they should. The key results are that the standard economic mass variable, which reflects consumer demand, does not perform well when it comes to bilateral trade flows where intermediates are dominant. Finally, we consider new proxies for the economic mass variables and show that using the wrong mass variable may bias estimates of other coefficients.

\section{THEORY}

To introduce notation and fix ideas, we review the standard gravity derivation following Baldwin and Taglioni (2007). ${ }^{5}$ Using the well-known CES preference structure for differentiated varieties, spending in nation-d ('d' for destination) on a variety produced in nation-o ('o' for origin) is:

\footnotetext{
${ }^{4}$ On the monopolistic competition frameworks see Krugman (1980), Bergstrand (1985, 1989), Helpman and Krugman, (1985); on the Heckscher-Ohlin model see Deardorff (1998), on Ricardian models see Eaton and Kortum (2001); on Melitz (2003) model applications, see Chaney (2008), and Helpman, Melitz and Rubinstein (2008).
}

${ }^{5}$ Another well-known derivation is from Helpman and Krugman (1985); they start from (1) and make supply-side assumptions that turns $\mathrm{p}_{\mathrm{o}}$ into a constant, but makes $\mathrm{n}_{\mathrm{od}}$ proportional to nationo's GDP so the resulting gravity equation is similar - at least in the case of frictionless trade (the case they worked with in 1985). 


$$
v_{o d} \equiv\left(\frac{p_{o d}}{P_{d}}\right)^{1-\sigma} E_{d} ; \quad \sigma>1
$$

where $v_{o d}$ is the expenditure in destination country-d, $\mathrm{p}_{\text {od }}$ is the consumer price inside nation-d of a variety made in nation-o, $P_{d}$ is the nation-d CES price index of all varieties, $\sigma$ is the elasticity of substitution among varieties ( $\sigma>1$ is assumed throughout), and $E_{d}$ is the nation-d consumer expenditure.

From the well-known profit maximization exercise of producers based in nation-o, $p_{o d}=\mu_{o d} m_{o} \tau_{o d}$, where $\mu_{o d}$ is the optimal price mark-up, $m_{o}$ is the marginal costs, and $\tau_{o d}$ is the bilateral trade cost factor, i.e. 1 plus the ad valorem tariff equivalent of all natural and manmade barriers. The mark-up is identical for all destinations if we assume perfect competition or Dixit-Stiglitz monopolistic competition; in these cases, the price variation is characterised by "mill pricing", i.e. 100\% pass through of trade costs to consumers in the destination market. ${ }^{6}$

Here we work with Dixit-Stiglitz competition exclusively, so the mark-up is always $\sigma /(\sigma-1)$. This means the local consumer price is $p_{o o}=(\sigma /(\sigma-1)) m_{o} \tau_{o o}$, where $\tau_{o o}$ is unity as we assume away internal trade barriers. Using this and summing over all varieties (assuming symmetry of varieties by origin nation for convenience), we have:

$$
V_{o d}=n_{o} p_{o o}{ }^{1-\sigma} \frac{\tau_{o d}^{1-\sigma}}{P_{d}^{1-\sigma}} E_{d}
$$

where $V_{o d}$ is the aggregate value of the bilateral flow (measured in terms of the numeraire) from nation-o to nation-d; $n_{o}$ is the number (mass) of nation-o varieties (all of which are sold in nation-d as per the well-known results of the Dixit-Stiglitz-Krugman model).

To turn this expenditure function (with optimal prices) into a gravity equation, we impose the market-clearing condition. Supply and demand match when (2) - summed across all destinations (including nation-o's sales to itself) - equals nation-o's output. When there is no international sourcing of parts, the nation's output is its GDP, denoted here as $\mathrm{Y}_{\mathrm{o}}$. Thus the market-clearing condition is: $Y_{o}=n_{o} p_{o o}^{1-\sigma} \sum_{d} \tau_{o d}^{1-\sigma} P_{d}^{\sigma-1} E_{d}$. Solving this we obtain that $n_{o} p_{o o}^{1-\sigma}=Y_{o} / \Omega_{o}$ where $\Omega_{o}$ is the usual market-potential index (namely, the sum of partners' market sizes weighted by a distance-related weight that places lower weight on more remote destinations); specifically it is $\Omega_{o} \equiv \sum_{d} \tau_{o d}^{1-\sigma} P_{d}^{\sigma-1} E_{d}$. Plugging this into (2) yields the traditional gravity equation:

$$
V_{o d}=\tau_{o d}^{1-\sigma} E_{d} Y_{o} \frac{1}{P_{d}^{1-\sigma}} \frac{1}{\Omega_{o}}
$$

Here $P_{d}$ is the nation-d CES price index, while $\Omega_{o}$ is the nation-o market-potential index. It has become common to label the product $P_{d}^{1-\sigma} \Omega_{o}$ as the "multilateral trade resistance" term.

${ }^{6}$ If one works with the Ottaviano Tabuchi and Thisse (2002) monopolistic competition framework, the mark-up varies bilaterally and so mill-pricing is not optimal. 
However, it is insightful to keep in mind the fact that "multilateral trade resistance" is a combination of two well-known, well-understood, and frequently measured components.

In the typical gravity estimation, $E_{d}$ is proxied with nation-d's GDP, $Y_{d}$ is proxied with nationo's GDP, and $\tau$ is proxied with bilateral distance.

\subsection{Gravity when parts and components trade is important}

To extend the gravity equation to allow for parts and components trade among firms, we need a trade model where intermediate goods trade is explicitly addressed. It proves convenient to work with the Krugman and Venables (1996) "vertical linkages" model which focuses squarely on the role of intermediate goods. Here we present the basic assumptions and the manipulations that produce the modified gravity equation.

Krugman and Venables (1996) works with the standard new economic geography model where each nation has two sectors (a Walrasian sector, A, and a Dixit-Stiglitz monopolistic competition sector M), and a single primary factor, labour L. Production of A requires only L, but production of each variety of $X$ requires $L$ and a $C E S$ composite of all varieties as intermediate inputs (i.e. each variety is purchased both for final consumption and for use as an intermediate). Following Krugman and Venables (1996), the CES aggregate on the supply side is isomorphic to the standard CES consumption aggregate.

The indirect utility function for the typical consumer is:

$$
V=I / P^{c} ; \quad P^{c} \equiv p_{A}^{1-\alpha}(P)^{\alpha} ; \quad P \equiv\left(\int_{i \in G} p_{i}^{1-\sigma} d i\right)^{1 /(1-\sigma)}
$$

where $\mathrm{I}$ is consumer income, $\mathrm{P}^{\mathrm{c}}$ is the ideal consumer price index, $\mathrm{p}_{\mathrm{A}}$ is the price of $\mathrm{A}$, the parameter " $\alpha$ " is the Cobb-Douglas expenditure share for M-sector goods, $\sigma$ is the elasticity of substitution among varieties, $P$ is the CES price index for $M$ varieties, $p_{i}$ is the consumer price of variety $i$, and $G$ is the set of varieties available.

The cost function of a typical firm in a typical country is:

$$
C[w, P, x]=\left(F+a_{X} x\right) w^{1-\alpha} P^{\alpha}
$$

Here $\mathrm{x}$ is the output of a typical variety, $\mathrm{F}$ and $\mathrm{a}_{\mathrm{x}}$ are cost parameters, $\mathrm{w}$ is the wage, and $\alpha$ is the Cobb-Douglas cost share for intermediate inputs. ${ }^{7}$

As noted above, mill pricing is optimal under Dixit-Stiglitz monopolistic competition. This, combined with the identity of the elasticity of substitution, $\sigma$, for each good's use in consumption and production, tells us that the price of each variety will be identical across the two types of customers. Choosing units such that $\mathrm{a}_{\mathrm{x}}=1-1 / \sigma$, the landed price will be:

$$
p_{\text {od }}=\tau_{\text {od }} w_{o}^{1-\alpha} P_{o}^{\alpha} ; \quad \forall o, d
$$

${ }^{7}$ The assumption that the Cobb-Douglas parameter is identical in the consumer and producer CES price index is one of the strategic implications in the Krugman-Venables model; see their book for a careful examination of what happens when this is relaxed (Fujitu, Krugman and Venables 1999). The standard conclusion is that it does not qualitatively change results but it does significantly complicate the analysis in a way that requires numerical simulation. 
Using Shepard's and Hotelling's lemmas on (4) and (5), and adding the total demand for purchasers located in nation-d, we have an expression that is isomorphic to (2) except the definition of $\mathrm{E}$ now includes purchases by customers using the goods as intermediates:

$$
V_{o d}=n_{o} p_{o o}^{1-\sigma} \frac{\tau_{o d}^{1-\sigma}}{P_{d}^{1-\sigma}} E_{d} ; \quad E_{d} \equiv \alpha\left(I_{d}+n_{d} C_{d}\right)
$$

where $I_{d}$ is nation- $d$ 's consumer income and $C_{d}$ is the total cost of a typical nation- $d$ variety.

As before, we solve for the endogenous $n_{o} p_{o o}{ }^{1-\sigma}$ using the market-clearing condition. In this case, the value that nation-o must sell is the full value of its M-sector output (not just its value added). Under monopolistic competition's free entry assumption, the value of sales equals the value of full costs, so the market clearing equation becomes:

$$
n_{o} C_{o}=n_{o} p_{o o}^{1-\sigma} \Sigma_{d} \tau_{o d}^{1-\sigma} P_{d}^{1-\sigma} E_{d} ; \quad C_{o} \equiv C\left[w_{o}, P_{o}, x_{o}\right]
$$

where the cost function $\mathrm{C}$ is given in (5). Solving (8) and plugging the result into (7) yields a gravity equation modified to allow for intermediates goods trade, namely:

$$
V_{o d}=\tau_{o d}^{1-\sigma} E_{d} C_{o} \frac{1}{P_{d}^{1-\sigma}} \frac{1}{\Omega_{o}}
$$

where $\mathrm{E}_{\mathrm{d}}$ is defined in (7) and $\mathrm{C}_{\mathrm{o}}$ is defined in (8), and $\Omega_{o} \equiv \sum_{d} \tau_{o d}^{1-\sigma} P_{d}^{\sigma-1} E_{d}$.

Expression (9) is the gravity equation modified to allow for trade intermediates. The key differences show up in the definition of the economic "mass" variables since purchases are now driven both by consumer demand (for which income is the demand shifter) and intermediate demand (for which total production costs is the demand shifter).

\section{BREAKDOWN OF THE STANDARD GRAVITY MODEL}

This theory exercise suggests a key difference that should arise between gravity estimates on nations and time periods where most imports are consumer goods versus those where intermediates trade is important. Specifically, the standard practice of using the GDP of origin and destination countries as the 'mass' variables in the gravity equations is inappropriate for bilateral flows where parts and components are important. Of course, if the consumer- and producer-demand moves in synch - as they may in a steady-state situation - then GDP may be a reasonable proxy for both consumer and producer demand shifter. But if the role of vertical specialisation trade is changing over time, GDP should be less good at proxy-ing for the underlying demand shifters. For this reason, we expect that origin-country's GDP and destination country's GDP will have diminished explanatory power for those countries where value-chain trade is important.

These observations generate a number of testable hypotheses.

- The estimated coefficient on the GDPs should be lower for nations where parts trade is important, and should fall as the importance of parts trade rises.

- As vertical specialisation trade has become more important over time, the GDP point estimates should be lower for more recent years. 
- In those cases where the GDPs of the trade partners lose explanatory power, bilateral trade should be increasingly well explained by demand in third countries.

For example, China's imports should shift from being explained by China's GDP to being explained by its exports to, say, the US and the EU. There are two ways of phrasing this hypothesis. First, China's imports are a function of its exports rather than its own GDP. Second, China's imports are a function of US and EU GDP rather than its own, since US and EU GDP are critical determinants of their imports from China.

To check these conjectures, we estimate the standard gravity model for different sets of countries and sectors for a panel that spans the years 1967 to 2007 . We run standard log-linear gravity equations using pooled cross-section time series data, namely:

$$
\ln \left(V_{o d t}\right)=G+\alpha_{1} \ln \left(\frac{Y_{o t}}{\Omega_{o t}} \cdot \frac{E_{d t}}{P_{d t}{ }^{1-\sigma}}\right)+\alpha_{2} \ln \tau_{o d t}+\varepsilon_{o d t}
$$

A key econometric problem is that the price index $\mathrm{P}_{\mathrm{dt}}$ and the market potential index $\Omega_{\mathrm{ot}}$ are unobservable and yet include factors that enter the regressions independently (e.g. E, Y and $\tau$ ). Thus ignoring them can lead to serious biases.

If the econometrician is only interested in estimating the impact of a pair-specific variable - such as distance or tariffs - the standard solution is to put in time-varying country-specific fixed effects. This eliminates all the terms multiplied by $\alpha_{1}$ in equation (10). Plainly we cannot use this approach to investigate the impact of using GDPs as the economic mass proxies when trade in parts and components is important. We thus need other means of controlling for $\Omega_{o_{t}}$ and $P_{d t}$.

Our baseline specification accounts for the terms $\Omega_{o t}$ and $P_{d t}$ explicitly. As precise measures of $\Omega_{o t}$ and $P_{d t}$ are hard to construct, we perform robustness checks using fixed effects specifications. To ensure comparability with the fixed effects specification, in the key specifications we enter the importer's and exporter's economic mass as a single product-term into the equation, with the shortcoming of forcing the coefficient of the importer and exporter mass variables to be the same. Specifically, the term accounting for the product of the trade partners' economic mass is the product of importer- $d$ real GDP (so to account for $P_{d t}$ ) and of exporter- $o$ 's nominal GDP divided by a proxied for $\Omega_{o t}$, constructed adapting a method first introduced by Baier and Bergstrand (2001) namely:

$$
\Omega_{o t}=\left(\sum_{d} G D P_{d t} *\left(\text { Dist }_{o d}\right)^{1-\sigma}\right)^{\frac{1}{1-\sigma}}
$$

The elasticity value in the $\Omega_{o t}$ relationship has been set as $\sigma=4$, which corresponds to estimates proposed in empirical literature (e.g. Obstfeld and Rogoff, 2001 and Carrere 2006).

Turning to the trade cost variable, $\tau$, we introduce standard trade frictions, including log of bilateral distance, and dummies for contiguity, and common language. Moreover for robustness purposes we also test for additional time-varying trade frictions measured by cif-fob ratios, as proposed by Bergstrand and Egger (2010).

The data used for the bilateral trade flows, and the cif-fob ratios are taken from the UN COMTRADE database. GDPs are from the World Bank's World Development Indicators. 
Bilateral distances, contiguity, and common language are from the CEPII database. Data for Taiwan, which are missing from the UN databases, are from CHELEM (CEPII) and national accounts.

Estimation is by simple ordinary least squares with the standard errors clustered by bilateral pairs since we work in direction-specific trade flows rather than the more traditional average of bilateral flows.

\subsection{Empirical results}

In Table 1 we report the gravity equation estimates for all goods as well as for intermediate and final goods separately. Intermediate and final goods have been identified according to the UN Broad Economic Categories Classification (see appendix). The sample includes all the nations where data is available, namely 187 nations.

Coefficients have the expected signs and are statistically significant. For all six regressions (all goods, only intermediates, and only consumer goods with and without time fixed effects) the estimates are broadly similar. The mass variables are all estimated to be close to unity. The bilateral distance variable is negative and falls in the expected range. The additional trade cost measure, the cif/fob ratio, is always negative as expected for the sub-samples, but positive for the aggregate sample. Continuity and language always have the expected sign and fall in the usual ranges.

Table 1: Bilateral flows of total, intermediate and final goods, 187 nations, 2000-2007.

\begin{tabular}{|c|c|c|c|c|c|c|}
\hline \multirow[b]{2}{*}{ VARIABLES } & \multicolumn{2}{|c|}{ All goods } & \multicolumn{2}{|c|}{ Intermediates only } & \multicolumn{2}{|c|}{ Consumer goods only } \\
\hline & (1) & (2) & (3) & (4) & (5) & (6) \\
\hline $\ln \left(\mathrm{GDPo}_{\mathrm{t}} * \mathrm{GDPd}_{\mathrm{t}} / \Omega_{\mathrm{ot}} * \mathrm{Pdt}\right)$ & $\begin{array}{c}0.860 * * * \\
(0.006) \\
-\end{array}$ & $\begin{array}{c}0.865^{* * *} \\
(0.006) \\
-\end{array}$ & $\begin{array}{c}0.898 * * * \\
(0.007)\end{array}$ & $\begin{array}{c}0.905^{* * *} \\
(0.007)\end{array}$ & $\begin{array}{c}0.791 * * * \\
(0.008)\end{array}$ & $\begin{array}{c}0.796^{* * *} \\
(0.008)\end{array}$ \\
\hline $\ln ($ cif/fob ratio) & $\begin{array}{c}0.0833 * * * \\
(0.013)\end{array}$ & $\begin{array}{c}0.0798 * * * \\
(0.013)\end{array}$ & $\begin{array}{c}-0.189 * * * \\
(0.015)\end{array}$ & $\begin{array}{c}-0.184 * * * \\
(0.015)\end{array}$ & $\begin{array}{c}-0.341 * * * \\
(0.017)\end{array}$ & $\begin{array}{c}-0.338 * * * \\
(0.017)\end{array}$ \\
\hline In Distance & $\begin{array}{c}-0.775 * * * \\
(0.019)\end{array}$ & $\begin{array}{c}-0.777 * * * \\
(0.019)\end{array}$ & $\begin{array}{c}-0.851 * * * \\
(0.022)\end{array}$ & $\begin{array}{c}-0.855 * * * \\
(0.022)\end{array}$ & $\begin{array}{c}-0.758 * * * \\
(0.025)\end{array}$ & $\begin{array}{c}-0.760 * * * \\
(0.025)\end{array}$ \\
\hline Contiguity & $\begin{array}{c}1.575 * * * \\
(0.105)\end{array}$ & $\begin{array}{c}1.565 * * * \\
(0.105)\end{array}$ & $\begin{array}{c}1.711 * * * \\
(0.119)\end{array}$ & $\begin{array}{c}1.697 * * * \\
(0.119)\end{array}$ & $\begin{array}{c}1.356^{* * * *} \\
(0.127)\end{array}$ & $\begin{array}{c}1.347 * * * \\
(0.127)\end{array}$ \\
\hline Common language & $\begin{array}{c}0.966 * * * \\
(0.046)\end{array}$ & $\begin{array}{c}0.972 * * * \\
(0.046)\end{array}$ & $\begin{array}{c}0.997 * * * \\
(0.052)\end{array}$ & $\begin{array}{c}1.005 * * * \\
(0.052)\end{array}$ & $\begin{array}{c}1.186 * * * \\
(0.059)\end{array}$ & $\begin{array}{c}1.192 * * * \\
(0.059)\end{array}$ \\
\hline Constant & $\begin{array}{c}-28.61 * * * \\
(0.359)\end{array}$ & $\begin{array}{c}-28.74 * * * \\
(0.363)\end{array}$ & $\begin{array}{c}-30.84 * * * \\
(0.400)\end{array}$ & $\begin{array}{c}-31.03 * * * \\
(0.404)\end{array}$ & $\begin{array}{c}-26.87 * * * \\
(0.456)\end{array}$ & $\begin{array}{c}-27.02 * * * \\
(0.459)\end{array}$ \\
\hline Time dummies & & yes & & yes & & yes \\
\hline Observations & 62875 & 62875 & 62875 & 62875 & 58468 & 58468 \\
\hline R-squared & 0.627 & 0.628 & 0.585 & 0.587 & 0.479 & 0.480 \\
\hline
\end{tabular}

Source: Authors' calculations; Note: Dependent variable: imports + re-imports. Standard errors are clustered by bilateral pair. Robust standard errors are reported in parenthesis: $* * * \mathrm{p}<0.01, * * \mathrm{p}<0.05, * \mathrm{p}<0.1$ 
These Table 1 results confirm the findings of Bergstrand and Egger (2010), namely that the size of the estimated coefficients does not vary for consumer and intermediate goods. As such, it would seem that our concern about mis-estimating the gravity equation is misplaced. However, as noted above, if the consumer and intermediate trade is roughly proportional over time, GDP will be a reasonable proxy for both consumer income and gross value added. The real test of the stability of the parameters would be on a sample where the importance of intermediates trade was rising significantly.

Table 2: Bilateral flows of total goods among Factory Asia nations (1967-2008).

\begin{tabular}{|c|c|c|c|c|c|}
\hline \multirow[b]{2}{*}{ VARIABLES } & \multicolumn{3}{|c|}{ No time interactions } & \multicolumn{2}{|c|}{ Variable mass coefficient } \\
\hline & (1) & (2) & (3) & (4) & (5) \\
\hline $\ln \left(\mathrm{GDP}_{\mathrm{o}} \cdot \mathrm{GDP}_{\mathrm{d}} / \Omega_{\mathrm{o}} \cdot \mathrm{P}_{\mathrm{d}}\right)$ & $\begin{array}{c}0.725 * * * \\
(0009)\end{array}$ & $\begin{array}{c}0.725^{* * * *} \\
(0028)\end{array}$ & $0.764 * * *$ & $0.425 * * *$ & $0.504 * * *$ \\
\hline *years 1967-1986 & & & & $\begin{array}{c}0.318^{* * * *} \\
(0.048)\end{array}$ & $\begin{array}{c}0.278 * * * \\
(0.048)\end{array}$ \\
\hline *years 1987-1996 & & & & $\begin{array}{c}0.177 * * * \\
(0.027)\end{array}$ & $\begin{array}{c}0.164 * * * \\
(0.032)\end{array}$ \\
\hline *years 1998-2002 & & & & 0.007 & 0.00274 \\
\hline $\ln$ (Distance) & $\begin{array}{c}-0.258 * * * \\
(0.0570)\end{array}$ & $\begin{array}{l}-0.258 \\
(0.298)\end{array}$ & & $\begin{array}{l}-0.0414 \\
(0.297)\end{array}$ & \\
\hline Contiguity & $\begin{array}{c}0.188 * * * \\
(0.0682)\end{array}$ & $\begin{array}{c}0.188 \\
(0.386)\end{array}$ & & $\begin{array}{c}0.167 \\
(0.367)\end{array}$ & \\
\hline Colony & $\begin{array}{c}-0.487 * * * * \\
(0.101)\end{array}$ & $\begin{array}{l}-0.487 \\
(0.388)\end{array}$ & & $\begin{array}{l}0.0695 \\
(0.405)\end{array}$ & \\
\hline Common coloniser & $\begin{array}{c}-0.620 * * * \\
(0.116)\end{array}$ & $\begin{array}{c}-0.620^{*} \\
(0.325)\end{array}$ & & $\begin{array}{l}-0.296 \\
(0.324)\end{array}$ & \\
\hline Constant & $\begin{array}{c}-7.218 * * * \\
(0.433)\end{array}$ & $\begin{array}{c}-7.218 * * * \\
(2.281)\end{array}$ & $\begin{array}{c}-8.825 * * * \\
(0.485)\end{array}$ & $\begin{array}{l}-1.465 \\
(2.279)\end{array}$ & $\begin{array}{c}-2.632 * * \\
(1.178)\end{array}$ \\
\hline Time effects & yes & yes & & & \\
\hline Exporter*time effects & & & yes & yes & yes \\
\hline Importer*time effects & & & yes & yes & yes \\
\hline Pair effects & & & yes & yes & yes \\
\hline Clustered Standard Errors & & yes & yes & yes & yes \\
\hline Observations & 1722 & 1722 & 1722 & 1722 & 1722 \\
\hline R-squared & 0.833 & 0.833 & 0.936 & 0.851 & 0.948 \\
\hline
\end{tabular}

Source: Authors' calculations; Note: Standard errors are clustered by bilateral pair. Robust standard errors in parenthesis: *** $\mathrm{p}<0.01, * *$ $\mathrm{p}<0.05,{ }^{*} \mathrm{p}<0.1$. Factory Asia countries: Japan, Indonesia, Republic of Korea, Malaysia, Thailand, and Taiwan.

To check this, we turn to a sub-sample of nations where we a priori expect intermediate trade to be both very important and growing more rapidly than consumer trade. Specifically, we estimate a gravity model as in Table 1, but on bilateral trade between pairs of Factory Asia countries (i.e. Japan, Indonesia, Korea, Malaysia, Philippines, Thailand, and Taiwan). To gauge the stability of parameters, we interact period-dummies with the mass variable. The results, shown in Table 2, are quite different to those of Bergstrand and Egger (2010) and to those of Table 1.

The baseline regressions (without time interactions) show the fairly common result that the gravity model does not work well on Factory Asia nations. The estimated mass coefficient is fairly low at about 0.7 . The distance estimate, however, at -0.26 is much lower than the commonly observed -0.7 to -1.0 . When we include time interaction terms for the economic mass variable, we find that the coefficient is not stable over time. When the standard controls are included, see column (4), the base case estimate is 0.4 to which must be added the period 
coefficients which are 0.3 for the pre-Factory Asia period (Baldwin 2006), 0.2 for the 1987-1996 period, and essentially zero (and insignificant) for the post 1998 period.

Figure 1: GDP coefficients for Factory Asia countries, 1967-2008.

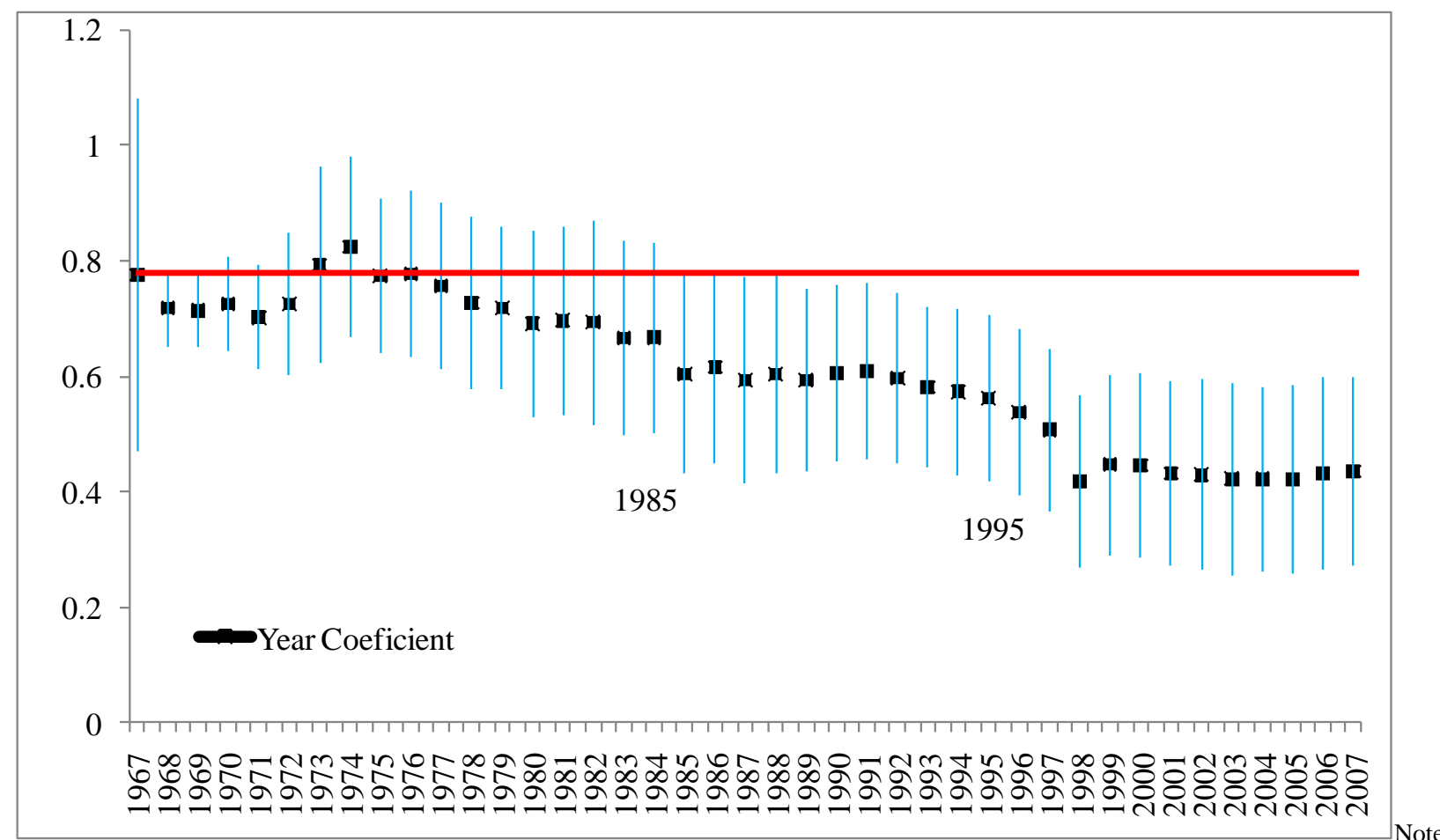

s: Estimated mass-elasticity coefficients with year interactions and pair fixed effects (as in (10). High and low bars show plus/minus 2 standard errors; Factory Asia countries: Japan, Indonesia, Republic of Korea, Malaysia, Thailand, and Taiwan.

To estimate the mass variable's instability over time more clearly, we re-do the same regression but allowing yearly interaction terms. The results, displayed in Figure 1, shows the evolution of the GDP coefficients. The mass elasticity fall over time, with two clear breaks in the estimated coefficients, 1985 and 1998.

The timing and direction of these structural changes are very much in line with the literature on the internationalisation of production. According to many studies, production unbundling started in the mid-1980s and accelerated in the 1990s (e.g. Hummels, Rapport and Yi 1998). The idea is that coordination costs fell with the ICT revolution and this permitted the spatial bundling of production stages (Baldwin 2006). The ICT revolution came in two phases. The internet came online in a massive way in the mid-1980s, and then, in the 1990s, the price of telecommunications plummeted with various ITC-related technical innovations and widespread deregulation (Baldwin 2011). The upshot of all these changes was that it became increasingly economical to geographically separate manufacturing stages. Stages of production that previously were performed within walking distance to facilitate face-to-face coordination could be dispersed without an enormous drop in efficiency or timeliness.

As far as the Figure 1 results are concerned, the notion is that as trade became increasingly focused on intermediates, GDP became an increasingly poor determinant of trade flows - as 
suggested by our theory. The impact of the mid-1980s changes and the mid-1990s changes are clear from the estimated GDP elasticities. More specifically, from 1967 to 1985 the elasticity of these countries' bilateral imports to GDP was stable, with a coefficient of about 0.77 . Between 1985 and 1997, it steadily decreased to reach a coefficient value of about 0.60 , and after 1998, it further dropped to a figure close to 0.40 . The coefficient estimates for the different periods in Factory Asia are summarised in Table 2 , columns (4) and (5).

Table 3: Estimates for EU15, and US, Canada, Australia and New Zealand, 1967-2008.

\begin{tabular}{|c|c|c|c|c|c|}
\hline \multirow{2}{*}{ VARIABLES } & \multicolumn{3}{|c|}{ No time interactions } & \multicolumn{2}{|c|}{ Variable mass coefficient } \\
\hline & (1) & (2) & (3) & (4) & (5) \\
\hline $\ln \left(\mathrm{GDP}_{\mathrm{o}} \cdot \mathrm{GDP}_{\mathrm{d}} / \Omega_{\mathrm{o}} \cdot \mathrm{P}_{\mathrm{d}}\right)$ & $\begin{array}{c}0.659 * * * \\
(0.009)\end{array}$ & $\begin{array}{c}0.659 * * * \\
(0.025)\end{array}$ & $\begin{array}{c}0.632 * * * \\
(0.027)\end{array}$ & $\begin{array}{c}0.725 * * * \\
(0.058)\end{array}$ & $\begin{array}{c}0.703 * * * \\
(0.034)\end{array}$ \\
\hline *years 1967-1986 & & & & $\begin{array}{c}-0.0408 \\
(0.051)\end{array}$ & $\begin{array}{l}-0.0503 \\
(0.044)\end{array}$ \\
\hline *years 1987-1996 & & & & $\begin{array}{c}-0.0376 \\
(0.036)\end{array}$ & $\begin{array}{l}-0.0444 \\
(0.032)\end{array}$ \\
\hline *years $1998-2002$ & & & & $\begin{array}{l}0.0132 \\
(0.017)\end{array}$ & $\begin{array}{c}0.005 \\
(0.014)\end{array}$ \\
\hline $\ln$ (Distance) & $\begin{array}{c}-0.843^{* * *} \\
(0.059)\end{array}$ & $\begin{array}{c}-0.843 * * * \\
(0.233)\end{array}$ & & $\begin{array}{c}-0.688 * * \\
(0.276)\end{array}$ & \\
\hline Constant & $\begin{array}{c}-1.630 * * \\
(0.726)\end{array}$ & $\begin{array}{l}-1.630 \\
(2.284)\end{array}$ & $\begin{array}{c}-8.819 * * * \\
(0.657)\end{array}$ & $\begin{array}{l}-4.966 \\
(3.733)\end{array}$ & $\begin{array}{c}-10.72 * * * \\
(0.917)\end{array}$ \\
\hline Time effects & yes & yes & & & \\
\hline Exporter*time effects & & & yes & yes & yes \\
\hline Importer*time effects & & & yes & yes & yes \\
\hline Pair effects & & & yes & yes & yes \\
\hline Observations & 820 & 820 & 820 & 820 & 820 \\
\hline R-squared & 0.932 & 0.932 & 0.978 & 0.934 & 0.978 \\
\hline Clustered Standard Errors & & yes & yes & yes & yes \\
\hline
\end{tabular}

Source: Authors' calculations; Note: Standard errors are clustered by bilateral pair. Robust standard errors are reported in parenthesis: $* * * \mathrm{p}<0.01, * * \mathrm{p}<0.05, * \mathrm{p}<0.1$.

For sake of comparison we also report results of time-year interactions with GDP for bilateral trade between countries where we a priori expect bilateral trade to be dominated by consumption goods and/or a stable ratio of intermediates to final goods trade. To this end, we re-run the Table 2 regressions for bilateral trade between each of the EU15 nations, and the US, Canada, Australia, and New Zealand. Because most of the internationalisation of supply chains is regional rather than global (except for microelectronics), we expect these bilateral trade flows to be less influenced by the second unbundling that so marked Factory Asia trade. The results, shown in Table 3 tend to confirm our view that the gravity model breaks down only for bilateral flows where production sharing is especially important and growing quickly. That is, as predicted by our theory, we find no breaks over time in the trade coefficients while distance coefficients have elasticity levels which are closer to unity. None of the time interaction terms in columns (4) and (5) are significant and the other point estimates fall in the expected ranges. 


\subsection{More precise estimates of the impact of components on the mass estimate}

These two sets of results are highly suggestive. On data that is widely recognised as being dominated by parts and components trade, we find structural instability in the mass variable coefficient moving in the expected direction. However, on data where this sort of production fragmentation is not widely viewed as having been important, we find that that mass pointestimates are stable over time.

To explore this more systematically, we consider a more continuous relationship between the importance of components trade and the point-estimate on the mass variable on the full sample. Our basic assertion is that the composition of trade flows will influence the point estimates of the economic mass variables since the standard gravity model is mis-specified when it comes to the mass variable. The most direct test of this hypothesis is to include the ratio of intermediates to total trade as a regressor, both on its own and - more importantly - as an interaction term with the economic mass variable. Of course a mis-specification of one part of the regression has implications for the point-estimates of the other regressors, so we also consider the ratio's interaction with the other main regressors.

To this end, we re-estimate the basic equation on the full sample of 187 countries for the years 2000-2008 allowing for interactions with a variable that accounts for the share of intermediate goods over total imports in each particular bilateral trade flow.

The idea here is that GDP as a measure for economic mass should work less well for those bilateral flows that are marked by relatively high shares of intermediates trade. By estimating the effect on the full sample, we avoid the problem of identifying the exact sources of the variation in the coefficients. We implement the idea in two ways.

First we estimate the standard regression but include the share of bilateral imports that is in intermediates (denoted as $M_{d}{ }^{\text {interm }} / M_{d}$ ). This new variable is included on its own and interacted with the other right-hand side variables. Table 4 reports the estimated results for the coefficients of interest.

The regression results tend to confirm our hypothesis. The regression reported in column (1) includes the ratio on its own and interacted only with the mass variable. The coefficients for economic mass and distance are a very reasonable at 1.031 and -1.173 respectively (both significant at the $1 \%$ level). The ratio on its own comes in positive as expected (bilateral tradelinks marked by a high share of intermediates tend to have 'too much' trade compared to the prediction of the standard gravity equation). The ratio interacted with economic mass also has a negative sign, -0.129 , which conforms with our hypothesis (the higher is the ratio of intermediates for the particular trade pair, the lower is the estimate of the economic mass variable). All coefficients are significantly different to zero at the $1 \%$ level of confidence.

The other columns report robustness checks on the main regression. The qualitative results on the variables of interest (the mass coefficient, the ratio coefficient, and the mass*ratio interaction coefficient) are robust to inclusion of interaction terms with any or all of the control variables. This confirms the more informal tests based on an a priori separation of the sample.

Interestingly, the interaction term is also highly significant and negative for distance in specification (2). That is, distance seems to matter more for components trade - a result that is not in line with our simple model, but is expected from the broader literature on offshoring. For 
example, transportation costs become more important when trade costs are incurred between each stage of production while the value added per stage is modest.

Table 4: Interactions with share of intermediates in total imports, full sample.

\begin{tabular}{|c|c|c|c|c|}
\hline VARIABLES & (1) & (2) & (3) & (4) \\
\hline$M_{d}^{\text {interm }} / M_{d}$ & $\begin{array}{c}6.536 * * * \\
(0.858)\end{array}$ & $\begin{array}{c}8.018 * * * \\
(1.015)\end{array}$ & $\begin{array}{c}6.954 * * * \\
(0.835)\end{array}$ & $\begin{array}{c}7.330 * * * \\
(1.004)\end{array}$ \\
\hline $\ln \left(\mathrm{GDP}_{\mathrm{o}} \cdot \mathrm{GDP}_{\mathrm{d}} / \Omega_{\mathrm{o}} \cdot \mathrm{P}_{\mathrm{d}}\right)$ & $\begin{array}{c}1.031 * * * \\
(0.010)\end{array}$ & $\begin{array}{c}1.027 * * * \\
(0.010)\end{array}$ & $\begin{array}{c}1.064 * * * \\
(0.010)\end{array}$ & $\begin{array}{c}1.058 * * * \\
(0.010)\end{array}$ \\
\hline$* \mathrm{M}_{\mathrm{d}}^{\mathrm{interm}} / \mathrm{M}_{\mathrm{d}}$ & $\begin{array}{c}-0.129 * * * \\
(0.017)\end{array}$ & $\begin{array}{c}-0.118 * * * \\
(0.017)\end{array}$ & $\begin{array}{c}-0.137 * * * \\
(0.017)\end{array}$ & $\begin{array}{c}-0.126 * * * \\
(0.016)\end{array}$ \\
\hline $\ln$ (Distance) & $\begin{array}{c}-1.173 * * * \\
(0.018)\end{array}$ & $\begin{array}{c}-1.051 * * * \\
(0.037)\end{array}$ & $\begin{array}{c}-1.011 * * * \\
(0.0191\end{array}$ & $\begin{array}{c}-0.954 * * * \\
(0.037)\end{array}$ \\
\hline$* \mathrm{M}_{\mathrm{d}}^{\mathrm{interm}} / \mathrm{M}_{\mathrm{d}}$ & & $\begin{array}{c}-0.232 * * * \\
(0.059)\end{array}$ & & $\begin{array}{l}-0.110^{*} \\
(0.0601\end{array}$ \\
\hline Contig $_{\text {od }}$ & & & $\begin{array}{c}1.350 * * * \\
(0.101)\end{array}$ & $\begin{array}{c}0.967 * * * \\
(0.246)\end{array}$ \\
\hline$* \mathrm{M}_{\mathrm{d}}^{\mathrm{interm}} / \mathrm{M}_{\mathrm{d}}$ & & & & $\begin{array}{l}0.625^{*} \\
(0.369)\end{array}$ \\
\hline Common language & & & $\begin{array}{c}1.215 * * * \\
(0.044)\end{array}$ & $\begin{array}{c}1.126 * * * \\
(0.078)\end{array}$ \\
\hline$* \mathrm{M}_{\mathrm{d}}^{\mathrm{interm}} / \mathrm{M}_{\mathrm{d}}$ & & & & $\begin{array}{c}0.178 \\
(0.119)\end{array}$ \\
\hline Constant & $\begin{array}{c}-27.58 * * * \\
(0.551)\end{array}$ & $\begin{array}{c}-28.40 * * * \\
(0.634)\end{array}$ & $\begin{array}{c}-30.85 * * * \\
(0.541)\end{array}$ & $\begin{array}{c}-31.07 * * * \\
(0.625)\end{array}$ \\
\hline Observations & 121737 & 121737 & 121737 & 121737 \\
\hline R-squared & 0.604 & 0.604 & 0.621 & 0.621 \\
\hline
\end{tabular}

Notes: $\mathrm{M}_{\mathrm{d}}^{\text {tinterm }} / \mathrm{M}_{\mathrm{d}}$ is the share of intermediate imports by a country $\mathrm{d}$ over its total imports. Robust standard errors are reported in parenthesis: $* * * \mathrm{p}<0.01, * * \mathrm{p}<0.05, * \mathrm{p}<0.1$.

The second approach is to use decile-dummies to permit a more flexible relationship between the share of imports made up of components and the mass point-estimate. The idea is that the inclusion of the intermediates-ratio imposes linearity on the relationship. The deciles approach allows the interaction terms to be non-linear, for example it allows for the possibility of a threshold effect whereby the interaction is significant but only for ratios that are sufficiently large. More specifically, the dummies categorises the share of intermediates in total imports, i.e. a dummy that selects bilateral flows where the proportion of intermediate imports is below 10\%, between $10 \%$ and $20 \%$, etc. The results are shown in Table 5. All results are robust to the addition of other trade determinants.

For the variable of greatest interest, the economic mass variable, the coefficient for the base-case decile is 0.985 which is very close to unity as expected and very precisely estimated. The subsequent rows show the additional effects for each decile. What we see is that the interaction terms are insignificant for shares of intermediates below $50 \%$ of total imports. However, for high concentrations of intermediates, the interaction terms are all negative and highly significant - at 
the $1 \%$ level. The additional effects lower the base case point-estimate by around 0.10 . The distance term is a very reasonable -1.1 and highly significant.

Table 5: All countries, 2000-2007, by share of intermediate imports.

\begin{tabular}{|c|c|c|c|}
\hline Variables & $\left(\mathrm{GDP}_{\mathrm{o}} \cdot \mathrm{GDP}_{\mathrm{d}} / \Omega_{\mathrm{o}} \cdot \mathrm{P}_{\mathrm{d}}\right)$ & $\ln ($ Distance $)$ & Constant \\
\hline Base effect & $\begin{array}{c}0.985 * * * \\
(0.018)\end{array}$ & $\begin{array}{c}-1.105^{* * *} \\
(0.018)\end{array}$ & $\begin{array}{c}-26.29 * * * \\
(0.898)\end{array}$ \\
\hline Base effect $* \mathrm{~d} 2$ & $\begin{array}{l}-0.0308 \\
(0.021)\end{array}$ & & \\
\hline Base effect $* d 3$ & $\begin{array}{l}0.0108 \\
(0.021)\end{array}$ & & \\
\hline Base effect $* \mathrm{~d} 4$ & $\begin{array}{l}-0.0330 \\
(0.020)\end{array}$ & & \\
\hline Base effect $* d 5$ & $\begin{array}{c}-0.0803 * * * \\
(0.020)\end{array}$ & & \\
\hline Base effect $* \mathrm{~d} 6$ & $\begin{array}{c}-0.103 * * * \\
(0.021)\end{array}$ & & \\
\hline Base effect $* d 7$ & $\begin{array}{c}-0.0903 * * * \\
(0.021)\end{array}$ & & \\
\hline Base effect $* d 8$ & $\begin{array}{c}-0.0723 * * * \\
(0.022)\end{array}$ & & \\
\hline Base effect $* d 9$ & $\begin{array}{c}-0.118 * * * \\
(0.024)\end{array}$ & & \\
\hline Base effect $* \mathrm{~d} 10$ & $\begin{array}{c}-0.0748 * * * \\
(0.022)\end{array}$ & & \\
\hline Observations & 121712 & & \\
\hline R-squared & 0.610 & & \\
\hline
\end{tabular}

Source: Authors' estimations; Note: deciles categorise countries bilateral imports by increasing shares of intermediate imports over total imports. Hence q10 indicates the $10 \%$ bilateral import relationships where the share of intermediate imports in total imports is highest and the base effect the $10 \%$ bilateral import relationships where the share of intermediate imports in total imports is lowest. Common language and contiguity included by not reported. Standard errors are clustered by bilateral pair. Robust standard errors are reported in parenthesis: $* * * \mathrm{p}<0.01, * * \mathrm{p}<0.05, * \mathrm{p}<0.1$

The results in Table 5 suggests that there is something of a threshold effect in operation. What we see is that the standard gravity specification works rather well for bilateral trade flows where the ratio of intermediates is not too great. For trade flows where intermediates are more important, however, we get the by now familiar result that the mass coefficient is significantly lower. Since this share is indeed rather low for most bilateral trade flows in the world (since production fragmentation tends to be a regional phenomenon), this may help explain the Baier and Egger (2010) result mentioned above.

To illustrate the point graphically, we plot, in Figure 2, the point estimates and standard errors using a candle chart. Here the point estimates of the mass coefficients are plotted as the horizontal bar; the associated standard errors are show with the vertical bar.

Figure 2: Coefficients by deciles for the standard mass proxy. 


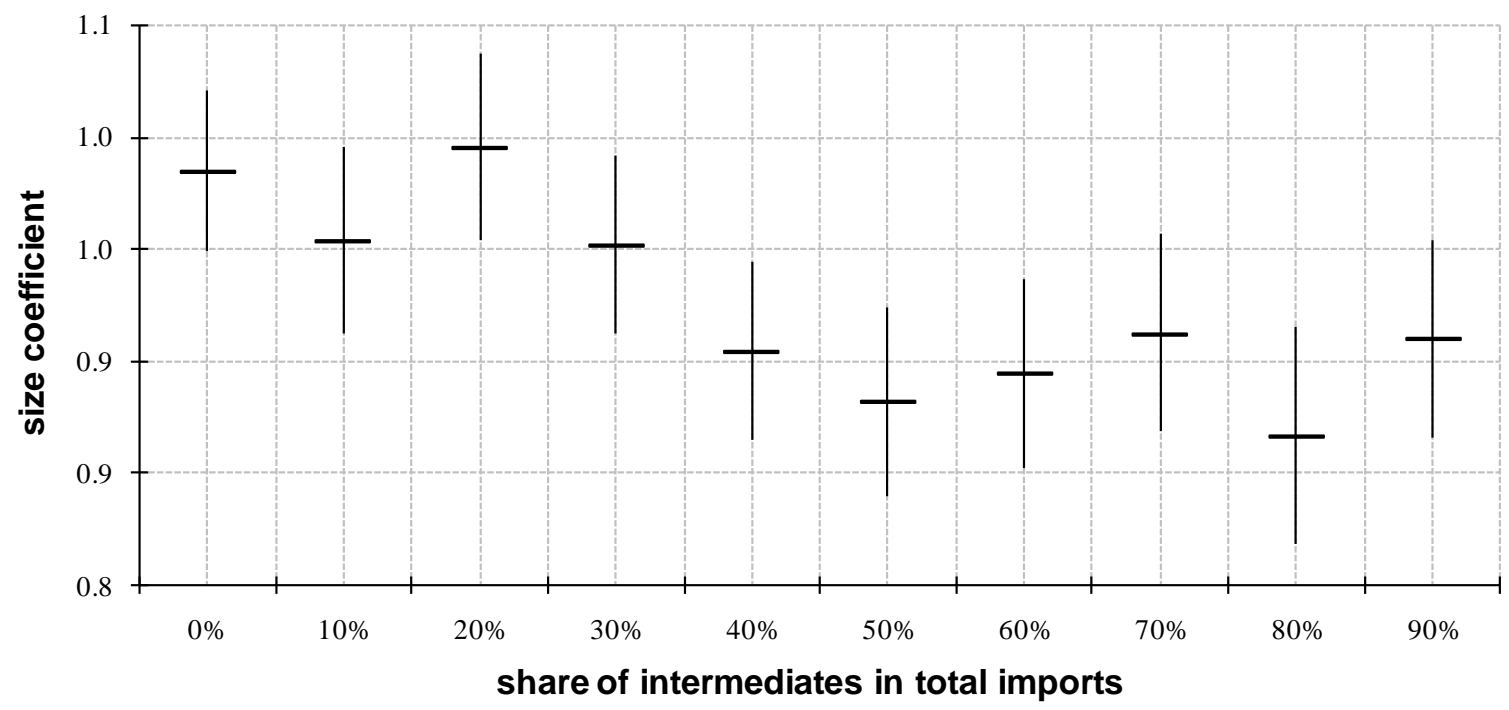

Source: Authors' estimations; Note: horizontal bars represent estimated coefficient and vertical bars twice the standard errors.

\section{A SEARCH FOR MASS PROXIES WHEN INTERMEDIATES ARE IMPORTANT}

The previous section provides clear evidence that the standard gravity equation is "broken" when it comes to bilateral flows where intermediates trade is important. The theory suggests that the perfect solution would require data on total costs to construct the demand shifter for intermediates imports. If the economy is reasonably competitive, gross sales would be a good proxy for the total costs. Unfortunately, such data are not available for a wide range of nations especially the developing nations where production fragmentation is so important. On the mass variable for the origin nation, theory suggests that we use gross output rather than value added. Again such data are not widely available.

This section presents the results of our search for a pragmatic "repair" which relies only on data that is available for a wide range of nations. The basic thrust is to use the theory in Section 2 to develop some proxies for economic mass variables that better reflect the fact that the demand for intermediates depends upon gross output, not value added.

\subsection{Fixes for economic mass proxies}

We start with the destination nation's mass variable. In Section 2 we showed that a bilateral flow of total goods is the sum of goods whose demand depends upon the importing nation's GDP (i.e. consumer goods) and goods whose demand depends upon the total costs of the sector buying the relevant intermediates. The theory says that our economic mass measure should be a linear combination of two mass measures, not a log-linear combination (see expressions (9) and (7)).

This suggests a first measure that adds imports of intermediates to GDP. The idea here is to exploit the direct definition of total costs as the cost of primary inputs plus the value of intermediate inputs. For any given local firm, some of the intermediates it purchases will be from local suppliers, but summing across all sectors and firms within a single nation, such intermediates will cancel out leaving only payments to local factors of production and imports of 
intermediates. Our first pragmatic fix therefore is to measure the destination nation's demand shifter by:

$$
E_{d} \equiv Y_{d}+\sum_{i \neq o} V_{d, i}^{\mathrm{interm}}
$$

where $\mathrm{V}^{\text {interm }}$ is the value of bilateral imports of intermediates. If we summed across all partners, this measure would include part of the bilateral flow to be explained (namely intermediates from nation-o to nation-d). To avoid putting the trade flow to be explained on both sides of the equation, we build the measure for each pair in a way that excludes the pair's bilateral trade.

For the economic mass variable size pertinent to the origin nation, we are trying to capture gross output that must be sold. The proposed measure is a straightforward application of the theory; it uses the origin nation's value added in manufacturing and its purchases of intermediate inputs from all sources except from itself (due to a lack of data).

$$
C_{o} \equiv A V_{o}^{\text {manuf }}+\sum_{i \neq 0} V_{i, o}^{\text {interm }}
$$

Note that our specification of the gravity equation uses the exports from nation-o to nation-d, so the second term in this does not include the bilateral flow to be explained. The second term involves nation-o's imports from all nations, not its exports to nations.

\subsection{Empirical results}

To test whether these proposed proxies work better than GDP, we run regressions like those reported in Table 4 but with the new proxies for economic mass replacing the standard proxy (i.e. GDP). The results are shown in Table 6.

The results in Table 6 - compared with those in Table 4 - suggest that our proxies work better than GDP. The key piece of evidence can be seen in column (1). This includes the ratio of intermediates in total bilateral trade both on its own and interacted with the mass variable. The lack of significant of the ratio in either role suggests that our new proxy is doing a better job than GDP did in picking up demand and supply of intermediates.

Interestingly, the column (2) regression, which allows an interaction between distances on the ratio of intermediates, suggests that the distance coefficient may also be mis-specified. When the ratio is interacted with distance, the distance estimate falls somewhat on average but especially for trade flows where parts and components are especially important (i.e. the ratio is high).

This suggests that distance is more important, not less, for bilateral trade flows dominated by intermediates. The finding may reflect the well-known fact that most production fragmentation arrangements are regional, not global (components trade is more regionalised that overall trade). This result, however intriguing, does not really stand up to minor changes in the specification. In regression (4), which includes the ratio's interaction with all variables, the distance result fades; indeed only the common language effect seems to be magnified for trade flows marked by particularly high ratios of intermediates.

Table 6: New mass proxies with share of intermediate, all nations, 2000-2007. 


\begin{tabular}{|c|c|c|c|c|}
\hline $\mathrm{M}_{\mathrm{d}}^{\text {interm }} / \mathrm{M}_{\mathrm{d}}$ & $\begin{array}{c}1.180 \\
(1.020)\end{array}$ & $\begin{array}{c}2.644 * * \\
(1.142)\end{array}$ & $\begin{array}{c}2.044 * * \\
(0.988)\end{array}$ & $\begin{array}{l}1.907 * \\
(1.143)\end{array}$ \\
\hline $\operatorname{Ln}\left(\mathrm{E}_{\mathrm{d}} \mathrm{C}_{\mathrm{o}} / \Omega_{\mathrm{o}} \mathrm{P}_{\mathrm{d}}\right)$ & $\begin{array}{c}0.898 * * * \\
(0.012)\end{array}$ & $\begin{array}{c}0.889 * * * \\
(0.0116)\end{array}$ & $\begin{array}{c}0.945 * * * \\
(0.012)\end{array}$ & $\begin{array}{c}0.932 * * * \\
(0.012)\end{array}$ \\
\hline$* \mathrm{M}_{\mathrm{d}}^{\mathrm{interm}} / \mathrm{M}_{\mathrm{d}}$ & $\begin{array}{l}-0.0322 \\
(0.020)\end{array}$ & $\begin{array}{l}-0.0132 \\
(0.020)\end{array}$ & $\begin{array}{l}-0.0289 \\
(0.020)\end{array}$ & $\begin{array}{l}-0.0247 \\
(0.020)\end{array}$ \\
\hline $\ln$ (Distance) & $\begin{array}{c}-1.080 * * * \\
(0.018)\end{array}$ & $\begin{array}{c}-0.929 * * * \\
(0.038)\end{array}$ & $\begin{array}{c}-0.908 * * * \\
(0.019)\end{array}$ & $\begin{array}{c}-0.838 * * * \\
(0.038)\end{array}$ \\
\hline$* \mathrm{M}_{\mathrm{d}}^{\text {interm }} / \mathrm{M}_{\mathrm{d}}$ & & $\begin{array}{c}-0.279 * * * \\
(0.065)\end{array}$ & & $\begin{array}{l}-0.131 * \\
(0.067)\end{array}$ \\
\hline Contig $_{\text {od }}$ & & & $\begin{array}{c}1.441 * * * \\
(0.092)\end{array}$ & $\begin{array}{c}1.211 * * * \\
(0.224)\end{array}$ \\
\hline$* \mathrm{M}_{\mathrm{d}}^{\text {interm }} / \mathrm{M}_{\mathrm{d}}$ & & & & $\begin{array}{c}0.356 \\
(0.354)\end{array}$ \\
\hline Common language & & & $\begin{array}{c}1.251 * * * \\
(0.047)\end{array}$ & $\begin{array}{c}1.047 * * * \\
(0.088)\end{array}$ \\
\hline$* \mathrm{M}_{\mathrm{d}}^{\mathrm{interm}} / \mathrm{M}_{\mathrm{d}}$ & & & & $\begin{array}{c}0.385^{* * *} \\
(0.143)\end{array}$ \\
\hline Constant & $\begin{array}{c}-20.05^{* * *} \\
(0.623)\end{array}$ & $\begin{array}{c}-20.87 * * * \\
(0.687)\end{array}$ & $\begin{array}{c}-24.17 * * * \\
(0.610)\end{array}$ & $\begin{array}{c}-24.08 * * * \\
(0.685)\end{array}$ \\
\hline Observations & 87258 & 87258 & 87258 & 87258 \\
\hline R-squared & 0.607 & 0.607 & 0.631 & 0.631 \\
\hline
\end{tabular}

Note: Robust standard errors are reported in parenthesis: $* * * \mathrm{p}<0.01, * * \mathrm{p}<0.05, * \mathrm{p}<0.1$; Pair effects, standard errors clustered by pair; $M_{d}{ }^{\text {interm }} / M_{d}$ is the share of intermediate imports by a country $d$ over its total imports. New mass variables defined in the text.

Importantly, we note that in all specifications, the ratio's interaction term on the economic mass is always insignificant. This suggests that our new mass proxies are doing a better job of picking up the true supply and demand variables including intermediates.

For symmetry, and to check for non-linear interaction terms, we use our new mass proxies in a regression akin to Table 5. The idea is to use ratio decile dummies instead of the ratio itself in order to allow the interactions to vary non-linearly for bilateral flows marked by different degrees of intermediates trade. The results are shown in Table 7.

To interpret our findings, recall that the significant of the upper-tier decile interaction terms was taken as evidence that GDP was not working well for trade flows marked by much trade in intermediates. Thus the results in Table 7 suggest that our new proxy is working better than GDP.

Specifically, the base-effect for our economic mass variable and the distance coefficients are estimated at very reasonable point estimates ( 0.88 and -1.1 respectively). Critically, only one of the decile interaction terms is significant, and it is positive, not negative as the theory would suggest. Two other interaction terms are borderline significant and negative, the ones for the sixths and tenth deciles. 
Table 7: New mass proxies with intermediate deciles, all nations, 2000-2007.

\begin{tabular}{|c|c|c|c|}
\hline & $\operatorname{Ln}\left(\mathrm{E}_{\mathrm{d}} \mathrm{C}_{\mathrm{o}} / \Omega_{\mathrm{o}} \mathrm{P}_{\mathrm{d}}\right)$ & $\ln$ (Distance) & Constant \\
\hline Base effect & $\begin{array}{c}0.877 * * * \\
(0.022)\end{array}$ & $\begin{array}{c}-1.051^{* * * *} \\
(0.018)\end{array}$ & $\begin{array}{c}-19.29 * * * \\
(1.074)\end{array}$ \\
\hline Base effect $* d 2$ & $\begin{array}{l}0.0402 \\
(0.024)\end{array}$ & & \\
\hline Base effect $* d 3$ & $\begin{array}{c}0.0365 * * * \\
(0.025)\end{array}$ & & \\
\hline Base effect $* \mathrm{~d} 4$ & $\begin{array}{l}0.0294 \\
(0.024)\end{array}$ & & \\
\hline Base effect $* \mathrm{~d} 5$ & $\begin{array}{l}-0.0256 \\
(0.024)\end{array}$ & & \\
\hline Base effect $* \mathrm{~d} 6$ & $\begin{array}{c}-0.0531 * * \\
(0.025)\end{array}$ & & \\
\hline Base effect $* \mathrm{~d} 7$ & $\begin{array}{l}-0.0390 \\
(0.025)\end{array}$ & & \\
\hline Base effect $* d 8$ & $\begin{array}{l}-0.0306 \\
(0.026)\end{array}$ & & \\
\hline Base effect $* d 9$ & $\begin{array}{c}-0.0652 * * \\
(0.028)\end{array}$ & & \\
\hline Base effect $* \mathrm{~d} 10$ & $\begin{array}{l}0.0102 \\
(0.027)\end{array}$ & & \\
\hline Observations & 87251 & & \\
\hline R-squared & 0.609 & & \\
\hline
\end{tabular}

Notes: See notes to Table 5.

\section{WHY DO INCORRECTLY SPECIFIED MASS VARIABLES MATTER?}

A large number of gravity studies focus on variable that vary across country pairs - say free trade agreements, cultural ties, or immigrant networks. The most recent of these studies employ estimators that control for the mass variables with fixed effects. ${ }^{8}$ Such studies do not suffer from mass-variable mis-specification and so are unaffected by our critique.

There are however as mentioned in the introduction, a number of recent studies - especially concerning the 'distance puzzle' that do proxy for the production and demand variables with GDP. It is these studies that our work speaks to. ${ }^{9}$

8 These econometric techniques were introduced by Harrigan (1996), Head and Mayer (2000), and Combes, Lafourcade and Mayer (2005), Anderson and Van Wincoop (2003), and Feenstra (2004).

${ }^{9}$ Rauch (1999), Brun et al (2005), Berthelon and Freund (2008), Jacks et al (2008), and Anderson and Van Wincoop (2003). 
However, since most of these studies are concerned with a broad set of nations and commodities, the mis-specification of the mass variable probably has a minor impact on the results - as the findings of Bergstrand and Egger (2010) showed and we confirmed with our Table 1 results. More worrying, however, is the use by authors that focus on trade in parts and components. ${ }^{10}$ These papers use the consumer-good version of the gravity model and thus mis-specify the mass variable.

Once the equation is mis-specified - in particular the standard economic mass proxies are not correctly reflecting the supply and demand constraints - we are in the realm of omitted variable biases. The first task is to explore the nature of the biases that would arise from this misspecification. To simplify, assume away GDPs and distance and focus on a pair-wise policy variable, say, nation-d's tariffs on imports from nation-o; we denote this as $\mathrm{T}_{\mathrm{od}}$. The estimated gravity equation will have the following structure:

$$
\ln V_{\text {odt }}=\text { constant }+\mathrm{a}_{5} \ln T_{\text {odt }}+\varepsilon_{\text {odt }}
$$

where the error is assumed to be iid.

Because intermediates supply is measured by total costs rather than GDP, and the supply of intermediates that must be sold depends upon gross output rather than value added. This means that the true model includes an additional term. That is:

$$
\ln V_{\text {odt }}=\mathrm{a}_{0}+\mathrm{a}_{5} \ln T_{\text {odt }}+\mathrm{a}_{6} \ln Z_{\text {odt }}+\varepsilon_{\text {odt }}
$$

where $\mathrm{Z}_{\text {odt }}$ is the difference between the GDP-based mass variables and the true mass variables as specified in (7). We can write $\mathrm{Z}_{\text {odt }}$ as a function of $\mathrm{T}_{\text {odt }}$ in an auxiliary regression:

$$
\ln Z_{o d t}=\mathrm{b}_{0}+b_{1} \ln T_{o d t}+u_{o d t}
$$

where $\mathrm{u}$ is assumed to be iid. Using this notation for the coefficients of the auxiliary regression, we can see that in estimating (13), we are actually estimating:

$$
\ln V_{\text {odt }}=\left(\mathrm{a}_{0}+b_{o} a_{6}\right)+\left(\mathrm{a}_{5}+\mathrm{a}_{6} \cdot b_{1}\right) \ln T_{o d t}+\left(\varepsilon_{o d t}+a_{6} u_{o d t}\right)
$$

What this tells us is that the coefficient on the policy variable of interest will almost surely be biased. The point is that the only way it is not biased is if there is no correlation between the misspecification of the economic mass variables and the policy variable.

What sort of correlation should we expect? Recall that the mis-measurement of the economic mass variable all goes back to the importance of trade in intermediate goods. Since almost all bilateral variables of interest are things that affect bilateral trade flows, it seems extremely likely that the variable of interest will also affect the flow of intermediates. As long as it does, then we know that the mis-specification of the mass variable will also lead to a bias in the pair-wise variables. ${ }^{11}$

${ }^{10}$ Athukorala and Yamashita (2006), Kimura et al (2007), Yokota and Kazuhiko (2008), and Ando and Kimura (2009).

${ }^{11}$ As noted above, the modern techniques for controlling for mass with time-varying countryspecific dummies eliminates such biases since they correctly control for the role of intermediates. 
For example, let us suppose that tariffs discourage trade overall, but they especially discourage intermediates trade (for the usual effective rate of protection reasons, i.e. the tariff is paid on the gross trade value but its incidence falls on the value added only). In this case, we should expect low tariffs to encourage two things, an overall increase in trade and an increase in the ratio of intermediates. In this case, the bias in the mis-specified gravity equation is likely to be negative, since the policy variable is negatively correlated with the omitted variable. Furthermore, the misspecification also affects the standard errors, which would result in a biased inference (Wooldridge, 2003, ch.4).

\section{CONCLUDING REMARKS}

In this paper we present empirical evidence that the standard gravity model performs poorly by some measures when it is applied to bilateral flows where parts and components trade is important. The paper also provides a simple theoretical foundation for a modified gravity equation that is suited to explaining trade where international supply chains are important. Finally we suggest ways in which the theoretical model can be implemented empirically.

\section{REFERENCES}

Anderson, James and Eric van Wincoop (2003). "Gravity with Gravitas: A Solution to the Border Puzzle," American Economic Review, vol. 93(1), pages 170-192,

Anderson, James and Eric van Wincoop, 2003. "Gravity with Gravitas: A Solution to the Border Puzzle," American Economic Review, American Economic Association, vol. 93(1), pages 170192, March.

Anderson, James and Yoto V. Yotov, 2010. "The Changing Incidence of Geography," American Economic Review, American Economic Association, vol. 100(5), pages 2157-86

Anderson, James, 1979, "The theoretical foundation for the gravity equation," American Economic Review 69, 106-116.

Ando, Mitsuyo and Fukunari Kimura (2009). "Fragmentation in East Asia: Further Evidence", ERIA Discussion Paper Series, DP-2009-20, October.

Athukorala, P. and N. Yamashita (2006), "Production Fragmentation and Trade Integration: East Asia in a Global Context", The North American Journal of Economics and Finance, 17, 3, 233256.

Balassa, Bela (1965), Economic Development and Integration. Centro de Estudios Monetarios Latinoamericanos.

Balassa, Bela (1966). "Tariff Reductions and Trade in Manufacturers among the Industrial Countries”, American Economic Review, Vol. 56, No. 3 (June), pp. 466-473.

Baldone, Salvatore, Fabio Sdogati and Lucia Tajoli (2007). "On Some Effects of International Fragmentation of Production on Comparative Advantages, Trade Flows and the Income of Countries," The World Economy, Blackwell Publishing, vol. 30(11), pages 1726-1769, November.

Baldwin, Richard (2006). "Globalisation: the great unbundling(s)", Chapter 1, in Globalisation challenges for Europe, Secretariat of the Economic Council, Finnish Prime Minister's Office, 
Helsinki, 2006, pp 5-47. http://hei.unige.ch/baldwin/PapersBooks/Unbundling_Baldwin_06-0920.pdf

Baldwin, Richard (2011). " $21^{\text {st }}$ century regionalism: Filling the gap between $21^{\text {st }}$ century trade and $20^{\text {th }}$ century trade governance", CEPR Policy Insight No. 56.

Baldwin, Richard and Daria Taglioni (2007). "Gravity for dummies and dummies for gravity equations" NBER WP 12516, published as "Trade effects of the euro: A comparison of estimators", Journal of Economic Integration, 22(4), December, pp 780-818. 2007.

Bergstrand, Jeffrey (1985), "The Gravity Equation in International Trade: Some Microeconomic Foundations and Empirical Evidence," Review of Economics and Statistics, 1985, 67:3, August, pp. 474-81.

Bergstrand, Jeffrey and Peter Egger (2010) "A General Equilibrium Theory for Estimating Gravity Equations of Bilateral FDI, Final Goods Trade and Intermediate Goods Trade", in S. Brakman and P. Van Bergeijk (eds) The Gravity Model in International Trade: Advances and Applications Cambridge University Press, New York.

Berthelon, Matias, and Caroline Freund (2008). "On the conservation of distance in international trade," Journal of International Economics, vol. 75(2), pages 310-320, July.

Brun, Jean-François, Céline Carrère, Patrick Guillaumont and Jaime de Melo (2005). "Has Distance Died? Evidence from a Panel Gravity Model," World Bank Economic Review, vol. 19(1), pages 99-120.

Coe, D., A. Subramanian, A. and N. Tamirisa (2007). The missing globalization puzzle: Evidence of the declining importance of distance. IMF Staff Papers, 1 (54), 34-58.

Dreze, Jacques (1961). "Les exportations intra-C.E.E, en 1958 et la position Beige". Recherches Economiques de Louvain, Vol. 27, 1961, pp. 717-738.

Egger Hartmut and Peter Egger, 2004. "Outsourcing and Trade in a Spatial World," CESifo Working Paper Series 1349, CESifo Group Munich.

Feenstra, Robert (1998). "Integration of Trade and Disintegration of Production in the Global Economy," Journal of Economic Perspectives-Volume 12, Number 4-Fall 1998-Pages 31-50.

Grossman, Gene M. and Esteban Rossi-Hansberg (2008). "Trading Tasks: A Simple Theory of Offshoring," American Economic Review, vol. 98(5), pages 1978-97, December.

Grubel, Herbert G., EJ. Lloyd (1975). Intra-Industry Trade: The Theory and Measurement of International Trade in Differentiated Products. London.

Grunwald, Joseph and Kenneth Flamm (1985). The global factory: Foreign assembly in international trade, Brookings Institution, Washington, DC.

Haddad, Mona (2007). "Trade integration in East Asia: the role of China and production networks," World Bank Policy Research Working Paper 4160, March.

Harrigan, James, 1996. "Openness to trade in manufactures in the OECD," Journal of International Economics, Elsevier, vol. 40(1-2), pages 23-39, February.

Helpman, Elhanan and Paul Krugman, 1985, Market structure and foreign trade, MIT Press. 
Helpman, Elhanan, Marc Melitz and Yona Rubinstein (2008). "Estimating Trade Flows: Trading Partners and Trading Volumes," The Quarterly Journal of Economics, MIT Press, vol. 123(2), pages 441-487, 05.

Hummels, D., D. Rapoport and K-M. Yi (1998). "Vertical Specialization and the Changing Nature of World Trade,", Federal Reserve Bank of New York Economic Policy Review (June), pp. 79-99.

Jacks, David, Christopher Meissner, and Dennis Novy (2008). “Trade Costs, 1870-2000”, American Economic Review, 98:2, 529-534.

Kimura, F., Y. Takahashi and K. Hayakawa (2007), "Fragmentation and Parts and Components Trade: Comparison between East Asia and Europe", The North American Journal of Economics and Finance, 18, 1, 23-40.

Kimura, Fukunari, Yuya Takahashi and Kazunobu Hayakawa (2007). "Fragmentation and parts and components trade: Comparison between East Asia and Europe," The North American Journal of Economics and Finance, vol. 18(1), pages 23-40.

Kimura, Fukunari, Yuya Takahashi, and Kazunobu Hayakawa (2007). "Fragmentation and parts and components trade: Comparison between East Asia and Europe," North American Journal of Economics and Finance, Volume 18, Issue 1, 1 February.

Krugman Paul and Anthony Venables (1996) "Intergration, specialisation, and adjustment" European Economic Review 40, pp. 959-967.

Lamy, Pascal (2010). “An urban legend about international trade”, speech 5 June 2010, http://other-news.info/index.php?p=3390.

Linneman, Hans (1966). "An econometric study of international trade flows, North-Holland, Amsterdam.

Novy, Denis (2010). "Trade Costs in the First Wave of Globalization" Explorations in Economic History 47(2), pp. 127-141.

Ottaviano, Gianmarco I.P., Takatoshi Tabuchi, and Jacques-François Thisse (2002).

"Agglomeration and Trade Revisited," International Economic Review, Vol. 43, pp. 409-436.

Poyhonen, Pentti (1963). "A tentative model for the volume of trade between countries," Weltwirtschaftliches Archiv, 90, pp 93-99.

Rauch, J., 1999. Networks versus markets in international trade. Journal of International Economics 48, 7-35.

Simon J. Evenett and Wolfgang Keller, 2002. "On Theories Explaining the Success of the Gravity Equation," Journal of Political Economy, University of Chicago Press, vol. 110(2), pages 281-316, April.

Tinbergen, Jan (1962). Shaping the world economy: Suggestions for an international economics policy, The Twentieth Century Fund, New York.

Vanek, Jaroslav (1963). "Variable Factor Proportions and Interindustry Flows in the Theory of International Trade," Quarterly Journal of Economics, LXXVII (Feb. 1963).

Yi, K-M (2003). “Can Vertical Specialization Explain the Growth of World Trade?” The Journal of Political Economy, Vol. 111, No. 1 (Feb.), pp. 52-102. 
Yokota, Kazuhiko (2008). "Parts and Components Trade and Production Networks in East Asia A Panel Gravity Approach", Chapter 3 in Hiratsuka \& Uchida eds., Vertical Specialization and Economic Integration in East Asia, Chosakenkyu-Hokokusho, IDE-JETRO, 2008.

\section{APPENDIX}

Classification for intermediate and final goods

\begin{tabular}{|l|l|}
\hline & BEC categories \\
\hline Intermediate goods: & 111 - Primary food and beverages, mainly for industry \\
121 - Processed food and beverages, mainly for industry \\
21 - Primary industrial supplies not elsewhere specified \\
22 - Processed industrial supplies not elsewhere specified \\
32 - Processed fuels and lubricants \\
42 - Parts and accessories of capital goods (except transport \\
equipment) \\
53 - Parts and accessories of transport equipment \\
\hline Consumption goods: & 112 - Primary food and beverages, mainly for household consumption \\
& 122 - Processed food and beverages, mainly for industry \\
& 51 - Passenger motor cars \\
6 & - Consumer goods not elsewhere specified \\
\hline Other: & 31 - Primary fuels and lubricants \\
41 - Capital goods, excluding parts and components \\
51 - Other transport equipment \\
7 - Other
\end{tabular}

Source: Comtrade's Broad Economic Categories; for details see http://unstats.un.org/unsd/tradekb/Knowledgebase/Intermediate-Goods-in-Trade-Statistics 